\title{
Gene expression profile of sodium channel subunits in the anterior cingulate cortex during experimental paclitaxel- induced neuropathic pain in mice
}

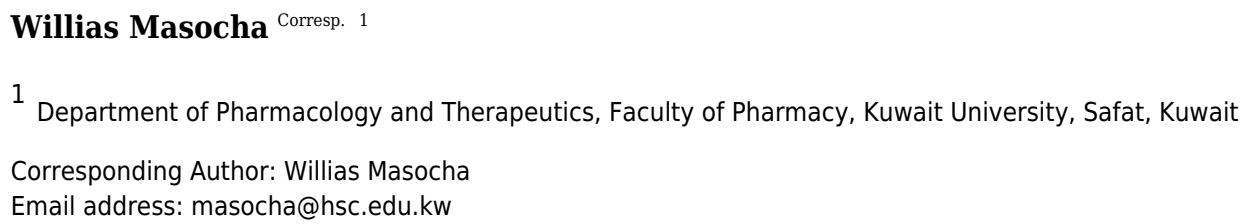

Paclitaxel, a chemotherapeutic agent, causes neuropathic pain whose supraspinal pathophysiology is not fully understood. Dysregulation of sodium channel expression, studied mainly in the periphery and spinal cord level, contributes to the pathogenesis of neuropathic pain. We examined gene expression of sodium channel (Nav) subunits by real time PCR in the anterior cingulate cortex (ACC) at day 7 post first administration of paclitaxel, when mice had developed paclitaxel-induced thermal hyperalgesia. The ACC was chosen because increased activity in the ACC has been observed during neuropathic pain. In the ACC of vehicle-treated animals the threshold cycle (Ct) values for Nav1.4, Nav1.5, Nav1.7, Nav1.8 and Nav1.9 were above 30 and/or not detectable in some samples. Thus, comparison in mRNA expression between untreated control, vehicletreated and paclitaxel treated animals was done for Nav1.1, Nav1.2, Nav1.3, Nav1.6, Nax as well as Nav $\beta 1-N a v \beta 4$. There were no differences in the transcript levels of Nav1.1Nav1.3, Nav1.6, Nax, Navß1-Navß3 between untreated and vehicle-treated mice, however, vehicle treatment increased Nav $\beta 4$ expression. Paclitaxel treatment significantly increased the mRNA expression of Nav1.1, Nav1.2, Nav1.6 and Nax, but not Nav1.3, sodium channel alpha subunits compared to vehicle-treated animals. Treatment with paclitaxel significantly increased the expression of $N a v \beta 1$ and $N a v \beta 3$, but not Nav $\beta 2$ and Nav $\beta 4$, sodium channel beta subunits compared to vehicle-treated animals. These findings suggest that during paclitaxel-induced neuropathic pain there is differential upregulation of sodium channels in the ACC, which might contribute to the increased neuronal activity observed in the area during neuropathic pain. 
1 Gene expression profile of sodium channel subunits in the anterior cingulate cortex during

2 experimental paclitaxel-induced neuropathic pain in mice

\section{Abstract}

5 Paclitaxel, a chemotherapeutic agent, causes neuropathic pain whose supraspinal

6 pathophysiology is not fully understood. Dysregulation of sodium channel expression, studied

7 mainly in the periphery and spinal cord level, contributes to the pathogenesis of neuropathic

8 pain. We examined gene expression of sodium channel $\left(\mathrm{Na}_{\mathrm{v}}\right)$ subunits by real time PCR in the

9 anterior cingulate cortex (ACC) at day 7 post first administration of paclitaxel, when mice had developed paclitaxel-induced thermal hyperalgesia. The ACC was chosen because increased activity in the $\mathrm{ACC}$ has been observed during neuropathic pain. In the ACC of vehicle-treated animals the threshold cycle $(\mathrm{Ct})$ values for $\mathrm{Na}_{\mathrm{v}} 1.4, \mathrm{Na}_{\mathrm{v}} 1.5, \mathrm{Na}_{\mathrm{v}} 1.7, \mathrm{Na}_{\mathrm{v}} 1.8$ and $\mathrm{Na}_{\mathrm{v}} 1.9$ were above 30 and/or not detectable in some samples. Thus, comparison in mRNA expression between untreated control, vehicle-treated and paclitaxel treated animals was done for $\mathrm{Na}_{\mathrm{v}} 1.1$, $\mathrm{Na}_{\mathrm{v}} 1.2, \mathrm{Na}_{\mathrm{v}} 1.3, \mathrm{Na}_{\mathrm{v}} 1.6, \mathrm{Na}_{\mathrm{x}}$ as well as $\mathrm{Na}_{\mathrm{v}} \beta 1-\mathrm{Na}_{\mathrm{v}} \beta 4$. There were no differences in the transcript levels of $\mathrm{Na}_{\mathrm{v}} 1.1-\mathrm{Na}_{\mathrm{v}} 1.3, \mathrm{Na}_{\mathrm{v}} 1.6, \mathrm{Na}_{\mathrm{x}}, \mathrm{Na}_{\mathrm{v}} \beta 1-\mathrm{Na}_{\mathrm{v}} \beta 3$ between untreated and vehicle-treated mice, however, vehicle treatment increased $\mathrm{Na}_{\mathrm{v}} \beta 4$ expression. Paclitaxel treatment significantly increased the mRNA expression of $\mathrm{Na}_{\mathrm{v}} 1.1, \mathrm{Na}_{\mathrm{v}} 1.2, \mathrm{Na}_{\mathrm{v}} 1.6$ and $\mathrm{Na}_{\mathrm{x}}$, but not $\mathrm{Na}_{\mathrm{v}} 1.3$, sodium channel alpha subunits compared to vehicle-treated animals. Treatment with paclitaxel significantly increased the expression of $\mathrm{Na}_{\mathrm{v}} \beta 1$ and $\mathrm{Na}_{\mathrm{v}} \beta 3$, but not $\mathrm{Na}_{\mathrm{v}} \beta 2$ and $\mathrm{Na}_{\mathrm{v}} \beta 4$, sodium channel beta subunits compared to vehicle-treated animals. These findings suggest that during paclitaxel-induced neuropathic pain there is differential upregulation of sodium channels in the 
23 ACC, which might contribute to the increased neuronal activity observed in the area during

24 neuropathic pain.

25 Willias Masocha

26 Department of Pharmacology and Therapeutics, Faculty of Pharmacy, Kuwait University, Safat,

27 Kuwait

28 Phone number: +965 24636078 Email: masocha@hsc.edu.kw

\section{Introduction}

30 Voltage-gated sodium channels $\left(\mathrm{Na}_{\mathrm{v}}\right)$ are responsible for action potential initiation and

31 propagation in neurons and other excitable cells. Sodium channels are composed of a pore-

32 forming $\alpha$ subunit associated with one or more auxiliary $\beta$ subunits that modulate channel gating,

33 expression and localisation (Catterall et al. 2005; Isom 2001). There are ten sodium channel $\alpha$

34 subunits $\mathrm{Na}_{\mathrm{v}} 1.1-\mathrm{Na}_{\mathrm{v}} 1.9$ and $\mathrm{Na}_{\mathrm{x}}$ encoded by genes SCN1A-SCN11A, and four $\beta$ subunits $\mathrm{Na}_{\mathrm{v}} \beta 1-$

$35 \mathrm{Na}_{\mathrm{v}} \beta 4$, encoded by genes SCN1B-SCN4B (Brackenbury \& Isom 2008; Cummins et al. 2007; Yu

36 \& Catterall 2003). These sodium channel subunits are expressed in a wide variety of tissues and

37 the level of expression of each channel varies between tissues.

38 Sodium channels play an important role in the propagation of nociceptive signals. Changes in

39 sodium channel function or expression can result in altered pain sensitivity and perception in

40 various conditions including neuropathic pain (Bagal et al. 2015; Cummins et al. 2007).

41 Dysregulated expression of sodium channels in both the periphery and the central nervous

42 system (CNS), which can result in frequent and ectopic firing in neurons, have been associated

43 with the pathogenesis of neuropathic pain (Craner et al. 2002; Lindia et al. 2005; Pertin et al.

44 2005; Rogers et al. 2006). 
45 In the periphery, the expression all sodium channel $\alpha$ subunits was downregulated, except for

$46 \mathrm{Na}_{\mathrm{v}} 1.2$, in the dorsal root ganglia (DRG) of rats with spared nerve injury (SNI) (Laedermann et

47 al. 2014). Another study observed downregulation of $\mathrm{Na}_{\mathrm{v}} 1.8$ and $\mathrm{Na}_{\mathrm{v}} 1.9$ in the $\mathrm{DRG}$ of a chronic

48 constriction injury (CCI) model of neuropathic pain (Dib-Hajj et al. 1999). However, other

49 studies have observed upregulation of sodium channel subunits such as Nav1.3, Nav1.6, Nav1.9,

$50 \mathrm{Na}_{\mathrm{v}} \beta 2$ and $\mathrm{Na}_{\mathrm{v}} \beta 3$ in the DRG of animal models of neuropathic pain (Craner et al. 2002; Lindia et

51 al. 2005; Pertin et al. 2005; Shah et al. 2001; Shah et al. 2000).

52 In the spinal cord $\mathrm{Na}_{\mathrm{v}} 1.3$ was also found to be upregulated in the dorsal horn neurons of CCI

53 and spinal cord injury (SCI) models of neuropathic pain (Hains et al. 2003; Hains et al. 2004).

54 Sciatic nerve injury (axotomy) resulted in upregulation of Nav1.7 in the spinal cord, which had

55 strong correlation with the level of pain behaviour (Persson et al. 2009). In a model of painful

56 diabetic neuropathy there was upregulation of $\mathrm{Na}_{\mathrm{v}} \beta 3$ expression in spinal cord (Shah et al. 2001).

$57 \mathrm{Na}_{\mathrm{v}} \beta 1$ expression increased whereas $\mathrm{Nav} \beta 2$ decreased in the spinal cord of neuropathic rats

58 (Blackburn-Munro \& Fleetwood-Walker 1999).

59 In the brain dysregulation of sodium channel expression has been observed in different areas

60 during neuropathic pain. In the prefrontal cortex $\mathrm{Na}_{\mathrm{v}} 1.1$ expression was upregulated in mice with

61 SNI (Alvarado et al. 2013). The expression of $\mathrm{Na}_{\mathrm{v}} 1.3$ was upregulated in the ventral

62 posterolateral (VPL) nucleus of the thalamus of rats with CCI or spinal cord contusion injury

63 (Hains et al. 2005; Zhao et al. 2006).

64 Recently, we observed increased excitability of the anterior cingulate cortex (ACC) to

65 electrophysiological stimulation in a rat model of paclitaxel-induced neuropathic pain (PINP)

66 (Nashawi et al. 2016). Paclitaxel is a chemotherapeutic drug whose therapeutic use is sometimes 
67 limited by the development of dose-dependent painful neuropathy (Scripture et al. 2006; Wolf et

68

69

70

71

72

73

74 al. 2008). The ACC is an area in the brain involved in pain perception and modulation, and has increased activity during neuropathic pain (Hsieh et al. 1995; Vogt 2005; Xie et al. 2009; Zhuo 2008). In previous studies, we observed changes in the expression of gamma-aminobutyric acid (GABA)-ergic and glutamatergic molecules in the ACC of a mouse model of PINP (Masocha 2015a; Masocha 2015b). However, the expression of sodium channels in the ACC during PINP has not been studied as yet. Studying the expression of sodium channels in the ACC during PINP is important as they might contribute to the increased neuronal excitability, which we observed in the ACC during PINP (Nashawi et al. 2016). Thus, in the current study the gene expression of sodium channel subunits in the ACC was evaluated in mice at a time point when the mice had paclitaxel-induced thermal hyperalgesia (Masocha 2015a; Nieto et al. 2008; Parvathy \& Masocha 2013). In previous studies, gene expression changes of other molecules were observed in the ACC of mice with paclitaxel-induced thermal hyperalgesia (Masocha 2015a; Masocha 2015b).

\section{Materials and Methods}

\section{Animals}

Female BALB/c mice ( 8 to 12 weeks old; 20 - $30 \mathrm{~g}$; $\mathrm{n}=49$ ) supplied by the Animal Resources Centre (ARC) at the Health Sciences Center (HSC), Kuwait University were used. The animals were kept in temperature controlled $\left(24 \pm 1^{\circ} \mathrm{C}\right)$ rooms with food and water given ad libitum. Animals were handled in compliance with the Kuwait University, HSC, ARC guidelines and in compliance with Directive 2010/63/EU of the European Parliament and of the Council on the protection of animals used for scientific purposes. All animal experiments were approved by the 
89 Ethical Committee for the use of Laboratory Animals in Teaching and in Research, HSC, Kuwait

90 University.

91 Paclitaxel administration

92 Paclitaxel (Cat. No. 1097, Tocris, Bristol, UK) was dissolved in a solution made up of 50\%

93 Cremophor EL and 50\% absolute ethanol to a concentration of $6 \mathrm{mg} / \mathrm{ml}$ and then diluted in

94 normal saline $(\mathrm{NaCl} 0.9 \%$ ), to a final concentration of $0.2 \mathrm{mg} / \mathrm{ml}$ just before administration.

95 Mice were treated intraperitoneally (i.p.) for 5 consecutive days with paclitaxel $2 \mathrm{mg} / \mathrm{kg}$, the

96 cumulative dose was $10 \mathrm{mg} / \mathrm{kg}$, or its vehicle. This treatment regimen produces painful

97 neuropathy and thermal hyperalgesia in mice on day 7 post first administration (Nieto et al.

98 2008; Parvathy \& Masocha 2013). A group of control mice was left untreated.

\section{Tissue preparation and Real time RT-PCR}

100 Mice were anesthetized with isoflurane, sacrificed by decapitation on day 7 post first

101 administration of paclitaxel. The ACC was dissected and prepared for RNA extraction as

102 described previously (Masocha 2015b)

103 Gene transcripts of the 10 sodium channel alpha subunits $\left(\mathrm{Na}_{\mathrm{v}} 1.1, \mathrm{Na}_{\mathrm{v}} 1.2, \mathrm{Na}_{\mathrm{v}} 1.3, \mathrm{Na}_{\mathrm{v}} 1.4\right.$,

$104 \mathrm{Na}_{\mathrm{v}} 1.5, \mathrm{Na}_{\mathrm{v}} 1.6, \mathrm{Na}_{\mathrm{v}} 1.7, \mathrm{Na}_{\mathrm{v}} 1.8, \mathrm{Na}_{\mathrm{v}} 1.9$ and $\left.\mathrm{Na}_{\mathrm{x}}\right)$ and 4 sodium channel beta subunits $\left(\mathrm{Na}_{\mathrm{v}} \beta 1\right.$,

$105 \mathrm{Na}_{\mathrm{v}} \beta 2, \mathrm{Na}_{\mathrm{v}} \beta 3$ and $\mathrm{Na}_{\mathrm{v}} \beta 4$ ) were quantified in the ACC of untreated, vehicle-treated and

106 paclitaxel-treated mice by real time PCR. Total RNA was extracted from the fresh frozen ACC

107 using the RNeasy Kit (Qiagen $\mathrm{GmbH}$ ), reverse-transcribed, and the mRNA levels were

108 quantified on an ABI Prism ${ }^{\circledR} 7500$ sequence detection system (Applied Biosystems) as

109 previously described (Masocha 2009; Masocha 2015a). The primer sequences which were used,

110 listed in Table 1, were ordered from Invitrogen (Life Technologies) and/or synthesized at the 
111 Research Core Facility (RCF), HSC, Kuwait University. Threshold cycle (Ct) values for all

112 cDNA samples were obtained and the amount of mRNA of individual animal sample (n $=8$ to 12

113 per group) was normalized to cyclophilin (housekeeping gene) $(\Delta \mathrm{Ct})$. The relative amount of

114 target gene transcripts was calculated using the $2^{-\Delta \Delta \mathrm{Ct}}$ method as described previously (Livak \&

115 Schmittgen 2001). These values were then used to calculate the mean and standard error of the

116 relative expression of the target gene mRNA in the ACC of paclitaxel- and vehicle-treated mice.

\section{Statistical analyses}

118 Statistical analyses were performed using Mann Whitney U test using Graph Pad Prism software

119 (version 5.0). The differences were considered significant at $\mathrm{p}<0.05$. The results in the text and

120 figures are expressed as the means \pm S.E.M. 
Results

122 The mRNA expression of sodium channel subunits were analysed in the ACC at day 7, a time

123 when the mice treated with paclitaxel had developed thermal hyperalgesia as we described

124 previously (Masocha 2014; Parvathy \& Masocha 2013) i.e. reduction in reaction latency

125 compared to the baseline latency and vehicle-treated mice $(5.7 \pm 0.3 \mathrm{~s}$ compared to $9.6 \pm 0.3 \mathrm{~s}$

126 and $9.3 \pm 0.3 \mathrm{~s}$, respectively; $\mathrm{n}=8$ vehicle-treated mice and 10 paclitaxel treated-mice; $\mathrm{p}<0.01$

127 for both comparisons).

\section{Expression of sodium channel alpha subunits transcripts in the ACC at 7 days after paclitaxel administration}

In vehicle-treated animals the $\mathrm{Ct}$ values for $\mathrm{Na}_{\mathrm{v}} 1.4, \mathrm{Na}_{\mathrm{v}} 1.5, \mathrm{Na}_{\mathrm{v}} 1.7, \mathrm{Na}_{\mathrm{v}} 1.8$ and $\mathrm{Na}_{\mathrm{v}} 1.9$ were above 30 and not detectable in some samples, whereas the $\mathrm{Ct}$ values for $\mathrm{Na}_{\mathrm{v}} 1.1, \mathrm{Na}_{\mathrm{v}} 1.2, \mathrm{Na}_{\mathrm{v}} 1.3$, $\mathrm{Na}_{\mathrm{v}} 1.6$ and $\mathrm{Na}_{\mathrm{x}}$ were below 30 . Thus, comparison in mRNA expression between control and paclitaxel treated animals was done for $\mathrm{Na}_{\mathrm{v}} 1.1, \mathrm{Na}_{\mathrm{v}} 1.2, \mathrm{Na}_{\mathrm{v}} 1.3, \mathrm{Na}_{\mathrm{v}} 1.6$ and $\mathrm{Na}_{\mathrm{x}}$.

Treatment with vehicle did not alter the expression of the 5 sodium channel alpha subunits evaluated, $\mathrm{Na}_{\mathrm{v}} 1.1(\mathrm{p}=1.000), \mathrm{Na}_{\mathrm{v}} 1.2(\mathrm{p}=0.1143), \mathrm{Na}_{\mathrm{v}} 1.3(\mathrm{p}=0.6857), \mathrm{Na}_{\mathrm{v}} 1.6(\mathrm{p}=0.3429)$ and $\mathrm{Na}_{\mathrm{x}}(\mathrm{p}=0.3429)$, compared to untreated control (Figures $1 \mathrm{~A}$ and $\left.2 \mathrm{~A}\right)$. Amongst the 5 sodium channel alpha subunits $\left(\mathrm{Na}_{\mathrm{v}} 1.1, \mathrm{Na}_{\mathrm{v}} 1.2, \mathrm{Na}_{\mathrm{v}} 1.3, \mathrm{Na}_{\mathrm{v}} 1.6\right.$ and $\left.\mathrm{Na}_{\mathrm{x}}\right)$ treatment with paclitaxel did not significantly alter the mRNA expression of the $\mathrm{Na}_{\mathrm{v}} 1.3(\mathrm{p}=0.1379)$, but significantly increased the expression of $\mathrm{Na}_{\mathrm{v}} 1.1$ by $2.1 \pm 0.2$ fold $(\mathrm{p}=0.0002), \mathrm{Na}_{\mathrm{v}} 1.2$ by $6.2 \pm 1.6$ fold $(\mathrm{p}=$ 0.0003), $\mathrm{Na}_{\mathrm{v}} 1.6$ by $3.8 \pm 0.7$ fold $(\mathrm{p}=0.0051)$, compared to vehicle-treated controls (Figure 1B). $\mathrm{Na}_{\mathrm{x}}$ was significantly upregulated by $7.6 \pm 2.2$ fold $(\mathrm{p}=0.0012)$ in the ACC by treatment with paclitaxel compared to treatment with vehicle (Figure 2B). The most upregulated sodium 
143 channel alpha subunits were $\mathrm{Na}_{\mathrm{v}} 1.2$ and $\mathrm{Na}_{\mathrm{x}}$, which were increased by more than sixfold after

144 treatment with paclitaxel.

145 Expression of sodium channel beta subunits transcripts in the ACC at 7 days after 146 paclitaxel administration

147 Treatment with vehicle did not alter the expression of 3 sodium channel beta subunits, Nav $\beta 1(p$ $148=0.2000), \operatorname{Nav} \beta 2(p=0.4857), \operatorname{Nav} \beta 3(p=0.6857)$, but significantly increased the expression of $149 \mathrm{Nav} \beta 4(\mathrm{p}=0.0286)$, compared to untreated control (Figure 3A). Amongst the 4 sodium channel 150 beta subunits analysed treatment with paclitaxel significantly increased the expression of $\mathrm{Na}_{\mathrm{v}} \beta 1$

151 by $2.8 \pm 0.5$ fold $(\mathrm{p}=0.0047)$ and $\mathrm{Na}_{\mathrm{v}} \beta 3$ by $4.4 \pm 1.1$ fold $(\mathrm{p}=0.0127)$, but not $\mathrm{Na}_{\mathrm{v}} \beta 2(\mathrm{p}=$

$1520.2301)$ and $\mathrm{Na}_{\mathrm{v}} \beta 4(\mathrm{p}=0.0525)$, compared to vehicle-treated controls (Figure 3$)$. The most

153 upregulated sodium channel beta subunit was $\mathrm{Na}_{\mathrm{v}} \beta 3$, which was increased by more than fourfold 154 after treatment with paclitaxel.

\section{Discussion}

156 This study presents the first comprehensive analysis of the expression of transcripts of sodium 157 channel subunits in the ACC during neuropathic pain, specifically paclitaxel-induced neuropathic pain (PINP). The ACC is an area of the brain associated with pain perception and modulation (Vogt 2005; Xie et al. 2009; Zhuo 2008).

No reports about the expression of sodium channels in the ACC specifically were found. However, $\mathrm{Na}_{\mathrm{v}} 1.1, \mathrm{Na}_{\mathrm{v}} 1.2, \mathrm{Na}_{\mathrm{v}} 1.3, \mathrm{Na}_{\mathrm{v}} 1.6$ and also $\mathrm{Na}_{\mathrm{x}}$ have been reported to be expressed predominantly (but not exclusively) in the brain with differential expression in different brain areas such as hippocampus, thalamus, cerebellum etc. (Beckh et al. 1989; Catterall 2000; Gautron et al. 1992; Levy-Mozziconacci et al. 1998; Schaller \& Caldwell 2003; Westenbroek et 
166 principally in the skeletal muscle, $\mathrm{Na}_{\mathrm{v}} 1.5$ is mainly expressed in cardiac muscle, while $\mathrm{Na}_{\mathrm{v}} 1.7$,

$167 \mathrm{Na}_{\mathrm{v}} 1.8$ and $\mathrm{Na}_{\mathrm{v}} 1.9$ are expressed preferentially in peripheral neurons (Cummins et al. 2007; Dib-

168 Hajj et al. 2015). In the current study using real time PCR all the $10 \alpha$ subunits and $4 \beta$ subunits

169 were detected in the ACC with different degrees of expression. $\mathrm{Na}_{\mathrm{v}} 1.1, \mathrm{Na}_{\mathrm{v}} 1.2, \mathrm{Na}_{\mathrm{v}} 1.3, \mathrm{Na}_{\mathrm{v}} 1.6$

170 and $\mathrm{Na}_{\mathrm{x}}$ as well as $\mathrm{Na}_{\mathrm{v}} \beta 1-\mathrm{Na}_{\mathrm{v}} \beta 4$ were highly expressed in the ACC. On the other hand,

171 although $\mathrm{Na}_{\mathrm{v}} 1.4, \mathrm{Na}_{\mathrm{v}} 1.5, \mathrm{Na}_{\mathrm{v}} 1.7, \mathrm{Na}_{\mathrm{v}} 1.8$ and $\mathrm{Na}_{\mathrm{v}} 1.9$ were detected in the ACC they were lowly

172 expressed and/or were not detectable in some samples. Thus, the findings of this study are in

173 agreement with studies described above. This suggests that the different sodium channel subunits

174 have different roles in the ACC and the brain in general. $\mathrm{Na}_{\mathrm{v}} 1.1, \mathrm{Na}_{\mathrm{v}} 1.2, \mathrm{Na}_{\mathrm{v}} 1.3, \mathrm{Na}_{\mathrm{v}} 1.6$ and $\mathrm{Na}_{\mathrm{x}}$

175 as well as $\mathrm{Na}_{\mathrm{v}} \beta 1-\mathrm{Na}_{\mathrm{v}} \beta 4$ most likely have more important roles in neuronal activity in the ACC

176 than $\mathrm{Na}_{\mathrm{v}} 1.4, \mathrm{Na}_{\mathrm{v}} 1.5, \mathrm{Na}_{\mathrm{v}} 1.7, \mathrm{Na}_{\mathrm{v}} 1.8$ and $\mathrm{Na}_{\mathrm{v}} 1.9$. This could be important for drug development

177 of specific sodium channel blockers; for example a specific blocker of $\mathrm{Na}_{\mathrm{v}} 1.1$ or $\mathrm{Na}_{\mathrm{v}} 1.2$ would

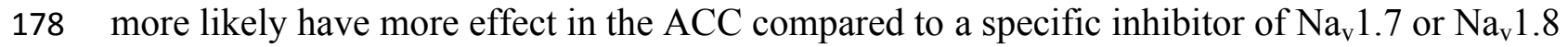

179 based on their expression patterns. Further studies are necessary to understand the specific

180 properties and activities of specific sodium channel subunits in the ACC under normal conditions

181 and during neuropathic pain.

182 Administration of tetrodotoxin (TTX), a voltage-gated sodium channel blocker, was reported to

183 prevent and treat signs of PINP such as thermal hyperalgesia, cold and mechanical allodynia in

184 mice, suggesting that TTX-sensitive voltage-gated sodium channels play a role in the

185 pathophysiology of PINP (Nieto et al. 2008). Mexiletine, a non-selective voltage-gated sodium

186 channel blocker was also found to have antinociceptive effects in rats with paclitaxel-induced

187 mechanical allodynia and hyperalgesia (Xiao et al. 2008). However, we found no studies that

188 investigated the expression of sodium channels in the periphery or CNS during PINP. In the 
189

190

191

192

193

194

195

196

197

198

199

200

201

202

203

204

205

206

207

208

209

210

211

current study, $\mathrm{Na}_{\mathrm{v}} 1.1, \mathrm{Na}_{\mathrm{v}} 1.2, \mathrm{Na}_{\mathrm{v}} 1.6$ and $\mathrm{Na}_{\mathrm{x}}$ as well as $\mathrm{Na}_{\mathrm{v}} \mathrm{B} 1$ and $\mathrm{Na}_{\mathrm{v}} \mathrm{B} 3$ were upregulated in the ACC of mice with paclitaxel-induced thermal hyperalgesia. Upregulation of sodium channel expression has been observed in other areas of the brain during neuropathic pain. In the prefrontal cortex $\mathrm{Na}_{\mathrm{v}} 1.1$ expression was upregulated in mice with SNI (Alvarado et al. 2013). Thus, our data are in agreement with the findings of Alvarado et al. and the suggestion that overexpression of $\mathrm{Na}_{\mathrm{v}} 1.1$ is involved in increased cortical excitability associated with chronic pain (Alvarado et al. 2013). It is also possible that the increased expression of $\mathrm{Na}_{\mathrm{v}} 1.2, \mathrm{Na}_{\mathrm{v}} 1.6, \mathrm{Na}_{\mathrm{x}}$, $\mathrm{Na}_{\mathrm{v}} \mathrm{B} 1$ and $\mathrm{Na}_{\mathrm{v}} \mathrm{B} 3$ in the $\mathrm{ACC}$ are involved in the increased excitability of this area observed during PINP (Nashawi et al. 2016). Although $\mathrm{Na}_{\mathrm{v}} 1.3$ was not significantly altered in the ACC during PINP it was reported to be upregulated in the ventral posterolateral (VPL) nucleus of the thalamus of rats with CCI and spinal cord contusion injury (Hains et al. 2005; Zhao et al. 2006). The findings of the current study suggest that upregulation of specific sodium channel subunits might contribute to hyperexcitability in the ACC. Hyperexcitability has been associated with dysregulation in sodium channels (Devor 2006). A link between upregulation of $\mathrm{Na}_{\mathrm{v}} 1.3$ and hyperexcitability of neurons in the spinal cord was found in neuropathic pain after spinal cord injury (Hains et al. 2003). Recently, we observed increased excitability of the ACC to electrophysiological stimulation in a rat model PINP (Nashawi et al. 2016), which could be in part be due upregulation of sodium channels amongst other mechanisms such as decreased GABA availability at the synapse because of increased GABA transporter 1 (GAT-1) expression (Masocha 2015b). Changes in the expression of other molecules such as those of the GABAergic, glutamatergic, muscarinic dopaminergic systems have also been observed in the ACC during experimental neuropathic pain (Masocha 2015a; Masocha 2015b; Ortega-Legaspi et al. 2011; Ortega-Legaspi et al. 2010). These findings suggest that the ACC plays an important 
212 role in the pathophysiology of PINP in addition to other brain areas, the spinal cord and

213 peripheral nerve damage. Paclitaxel has limited ability to cross the blood-brain barrier (Glantz et

214 al. 1995; Kemper et al. 2003), thus a direct effect of paclitaxel in the ACC is unlikely. In a rat

215 model paclitaxel induced microglial activation in the spinal cord (Peters et al. 2007). They

216 proposed (Peters et al. 2007) that paclitaxel-induced nerve injury possibly induced

217 neurochemical reorganization within the spinal cord leading to central sensitization (Cata et al.

218 2006) and that the microglial reaction they observed occurred as a result of degeneration of

219 central terminals of injured primary afferent fibers or possibly due to the spinal release of factors

220 from injured neurons rather than direct injury of spinal cord neurons by paclitaxel. In the

221 periphery paclitaxel causes nerve damage by direct effects on the neurons (Cavaletti et al. 2000;

222 Scuteri et al. 2006; Theiss \& Meller 2000) or via inflammation and the increased infiltration of

223 macrophages into the dorsal root ganglia (Peters et al. 2007; Zhang et al. 2016), which cause

224 further nerve damage. Thus, the changes observed in the ACC could be due to an increased

225 nociceptive input from the peripheral nerves damaged by paclitaxel resulting in central

226 sensitization. However, information on protein expression is critical to subsequently define the

227 meaning of expression changes in the mRNA level observed in the ACC.

\section{Conclusions}

230 In conclusion, the findings of this study show that sodium channel subunit transcripts are

231 differentially expressed in the ACC; with those known to be preferentially expressed in the CNS

232 being highly expressed in the ACC, whereas those known to be preferentially expressed in the

233 periphery being lowly expressed in the ACC. More importantly, the results show that during 
234 experimental paclitaxel-induced neuropathic pain there is increased expression of various sodium

235 channel subunit transcripts in the ACC, which could contribute to the increased excitability and 236 activity observed in this brain region during neuropathic pain.

237 


\section{Acknowledgements}

239 I am grateful to Dr Subramanian S Parvathy, Ms. Salini Soman, Ms. Amal Thomas from the

240 Department of Pharmacology and Therapeutics, Faculty of Pharmacy, for their technical

241 assistance and to the staff from the Animal Resources Centre, HSC, Kuwait University for their

242 support. 


\section{References}

244

245

246

247

248

249

250

251

252

253

254

255

256

257

258

259

260

261

262

263

264

265

266

267

268

269

270

271

272

273

274

275

276

277

278

279

280

281

282

283

284

285

286

287

288

Alvarado S, Tajerian M, Millecamps M, Suderman M, Stone LS, and Szyf M. 2013. Peripheral nerve injury is accompanied by chronic transcriptome-wide changes in the mouse prefrontal cortex. Mol Pain 9:21.

Bagal SK, Marron BE, Owen RM, Storer RI, and Swain NA. 2015. Voltage gated sodium channels as drug discovery targets. Channels (Austin) 9:360-366.

Beckh S, Noda M, Lubbert $H$, and Numa S. 1989. Differential regulation of three sodium channel messenger RNAs in the rat central nervous system during development. EMBO J 8:3611-3616.

Blackburn-Munro G, and Fleetwood-Walker SM. 1999. The sodium channel auxiliary subunits beta1 and beta 2 are differentially expressed in the spinal cord of neuropathic rats. Neuroscience 90:153164.

Brackenbury WJ, and Isom LL. 2008. Voltage-gated Na+ channels: potential for beta subunits as therapeutic targets. Expert Opin Ther Targets 12:1191-1203.

Cata JP, Weng HR, Lee BN, Reuben JM, and Dougherty PM. 2006. Clinical and experimental findings in humans and animals with chemotherapy-induced peripheral neuropathy. Minerva Anestesiol 72:151-169.

Catterall WA. 2000. From ionic currents to molecular mechanisms: the structure and function of voltagegated sodium channels. Neuron 26:13-25.

Catterall WA, Goldin AL, and Waxman SG. 2005. International Union of Pharmacology. XLVII. Nomenclature and structure-function relationships of voltage-gated sodium channels. Pharmacol Rev 57:397-409.

Cavaletti G, Cavalletti E, Oggioni N, Sottani C, Minoia C, D'Incalci M, Zucchetti M, Marmiroli P, and Tredici G. 2000. Distribution of paclitaxel within the nervous system of the rat after repeated intravenous administration. Neurotoxicology 21:389-393.

Craner MJ, Klein JP, Renganathan M, Black JA, and Waxman SG. 2002. Changes of sodium channel expression in experimental painful diabetic neuropathy. Ann Neurol 52:786-792.

Cummins TR, Sheets PL, and Waxman SG. 2007. The roles of sodium channels in nociception: Implications for mechanisms of pain. Pain 131:243-257.

Devor M. 2006. Sodium channels and mechanisms of neuropathic pain. J Pain 7:S3-S12.

Dib-Hajj SD, Black JA, and Waxman SG. 2015. NaV1.9: a sodium channel linked to human pain. Nat Rev Neurosci 16:511-519.

Dib-Hajj SD, Fjell J, Cummins TR, Zheng Z, Fried K, LaMotte R, Black JA, and Waxman SG. 1999. Plasticity of sodium channel expression in DRG neurons in the chronic constriction injury model of neuropathic pain. Pain 83:591-600.

Gautron S, Dos Santos G, Pinto-Henrique D, Koulakoff A, Gros F, and Berwald-Netter Y. 1992. The glial voltage-gated sodium channel: cell- and tissue-specific mRNA expression. Proc Natl Acad Sci U S A 89:7272-7276.

Glantz MJ, Choy H, Kearns CM, Mills PC, Wahlberg LU, Zuhowski EG, Calabresi P, and Egorin MJ. 1995. Paclitaxel disposition in plasma and central nervous systems of humans and rats with brain tumors. J Natl Cancer Inst 87:1077-1081.

Hains BC, Klein JP, Saab CY, Craner MJ, Black JA, and Waxman SG. 2003. Upregulation of sodium channel Nav1.3 and functional involvement in neuronal hyperexcitability associated with central neuropathic pain after spinal cord injury. J Neurosci 23:8881-8892.

Hains BC, Saab CY, Klein JP, Craner MJ, and Waxman SG. 2004. Altered sodium channel expression in second-order spinal sensory neurons contributes to pain after peripheral nerve injury. $J$ Neurosci 24:4832-4839. 
Hains BC, Saab CY, and Waxman SG. 2005. Changes in electrophysiological properties and sodium channel Nav1.3 expression in thalamic neurons after spinal cord injury. Brain 128:2359-2371.

Hsieh JC, Belfrage M, Stone-Elander S, Hansson P, and Ingvar M. 1995. Central representation of chronic ongoing neuropathic pain studied by positron emission tomography. Pain 63:225-236.

Isom LL. 2001. Sodium channel beta subunits: anything but auxiliary. Neuroscientist 7:42-54.

Kemper EM, van Zandbergen AE, Cleypool C, Mos HA, Boogerd W, Beijnen JH, and van Tellingen O. 2003. Increased penetration of paclitaxel into the brain by inhibition of P-Glycoprotein. Clin Cancer Res 9:2849-2855.

Laedermann CJ, Pertin M, Suter MR, and Decosterd I. 2014. Voltage-gated sodium channel expression in mouse DRG after SNI leads to re-evaluation of projections of injured fibers. Mol Pain 10:19.

Levy-Mozziconacci A, Alcaraz G, Giraud P, Boudier JA, Caillol G, Couraud F, and Autillo-Touati A. 1998. Expression of the mRNA for the beta 2 subunit of the voltage-dependent sodium channel in rat CNS. Eur J Neurosci 10:2757-2767.

Lindia JA, Kohler MG, Martin WJ, and Abbadie C. 2005. Relationship between sodium channel NaV1.3 expression and neuropathic pain behavior in rats. Pain 117:145-153.

Livak KJ, and Schmittgen TD. 2001. Analysis of relative gene expression data using real-time quantitative PCR and the 2(-Delta Delta C(T)) Method. Methods 25:402-408.

Masocha W. 2009. Systemic lipopolysaccharide (LPS)-induced microglial activation results in different temporal reduction of CD200 and CD200 receptor gene expression in the brain. J Neuroimmunol 214:78-82.

Masocha W. 2014. Paclitaxel-induced hyposensitivity to nociceptive chemical stimulation in mice can be prevented by treatment with minocycline. Sci Rep 4:6719.

Masocha W. 2015a. Astrocyte activation in the anterior cingulate cortex and altered glutamatergic gene expression during paclitaxel-induced neuropathic pain in mice. PeerJ 3:e1350.

Masocha W. 2015b. Comprehensive analysis of the GABAergic system gene expression profile in the anterior cingulate cortex of mice with Paclitaxel-induced neuropathic pain. Gene Expr 16:145153.

Nashawi H, Masocha W, Edafiogho IO, and Kombian SB. 2016. Paclitaxel Causes Electrophysiological Changes in the Anterior Cingulate Cortex via Modulation of the gamma-Aminobutyric Acid-ergic System. Med Princ Pract 25:423-428.

Nieto FR, Entrena JM, Cendan CM, Pozo ED, Vela JM, and Baeyens JM. 2008. Tetrodotoxin inhibits the development and expression of neuropathic pain induced by paclitaxel in mice. Pain 137:520531.

Ortega-Legaspi JM, de Gortari P, Garduno-Gutierrez R, Amaya MI, Leon-Olea M, Coffeen U, and Pellicer F. 2011. Expression of the dopaminergic D1 and D2 receptors in the anterior cingulate cortex in a model of neuropathic pain. Mol Pain 7:97.

Ortega-Legaspi JM, Leon-Olea M, de Gortari P, Amaya MI, Coffeen U, Simon-Arceo K, and Pellicer F. 2010. Expression of muscarinic $M 1$ and $M 2$ receptors in the anterior cingulate cortex associated with neuropathic pain. Eur J Pain 14:901-910.

Parvathy SS, and Masocha W. 2013. Matrix metalloproteinase inhibitor COL-3 prevents the development of paclitaxel-induced hyperalgesia in mice. Med Princ Pract 22:35-41.

Persson AK, Thun J, Xu XJ, Wiesenfeld-Hallin Z, Strom M, Devor M, Lidman O, and Fried K. 2009. Autotomy behavior correlates with the DRG and spinal expression of sodium channels in inbred mouse strains. Brain Res 1285:1-13.

Pertin M, Ji RR, Berta T, Powell AJ, Karchewski L, Tate SN, Isom LL, Woolf CJ, Gilliard N, Spahn DR, and Decosterd I. 2005. Upregulation of the voltage-gated sodium channel beta2 subunit in neuropathic pain models: characterization of expression in injured and non-injured primary sensory neurons. J Neurosci 25:10970-10980. 
Peters CM, Jimenez-Andrade JM, Jonas BM, Sevcik MA, Koewler NJ, Ghilardi JR, Wong GY, and Mantyh PW. 2007. Intravenous paclitaxel administration in the rat induces a peripheral sensory neuropathy characterized by macrophage infiltration and injury to sensory neurons and their supporting cells. Exp Neurol 203:42-54.

Rogers M, Tang L, Madge DJ, and Stevens EB. 2006. The role of sodium channels in neuropathic pain. Semin Cell Dev Biol 17:571-581.

Schaller KL, and Caldwell JH. 2003. Expression and distribution of voltage-gated sodium channels in the cerebellum. Cerebellum 2:2-9.

Scripture CD, Figg WD, and Sparreboom A. 2006. Peripheral neuropathy induced by paclitaxel: recent insights and future perspectives. Curr Neuropharmacol 4:165-172.

Scuteri A, Nicolini G, Miloso M, Bossi M, Cavaletti G, Windebank AJ, and Tredici G. 2006. Paclitaxel toxicity in post-mitotic dorsal root ganglion (DRG) cells. Anticancer Res 26:1065-1070.

Shah BS, Gonzalez MI, Bramwell S, Pinnock RD, Lee K, and Dixon AK. 2001. Beta3, a novel auxiliary subunit for the voltage gated sodium channel is upregulated in sensory neurones following streptozocin induced diabetic neuropathy in rat. Neurosci Lett 309:1-4.

Shah BS, Stevens EB, Gonzalez MI, Bramwell S, Pinnock RD, Lee K, and Dixon AK. 2000. beta3, a novel auxiliary subunit for the voltage-gated sodium channel, is expressed preferentially in sensory neurons and is upregulated in the chronic constriction injury model of neuropathic pain. Eur $J$ Neurosci 12:3985-3990.

Theiss C, and Meller K. 2000. Taxol impairs anterograde axonal transport of microinjected horseradish peroxidase in dorsal root ganglia neurons in vitro. Cell Tissue Res 299:213-224.

Vogt BA. 2005. Pain and emotion interactions in subregions of the cingulate gyrus. Nat Rev Neurosci 6:533-544.

Westenbroek RE, Merrick DK, and Catterall WA. 1989. Differential subcellular localization of the RI and RII Na+ channel subtypes in central neurons. Neuron 3:695-704.

Whitaker WR, Clare JJ, Powell AJ, Chen YH, Faull RL, and Emson PC. 2000. Distribution of voltage-gated sodium channel alpha-subunit and beta-subunit mRNAs in human hippocampal formation, cortex, and cerebellum. J Comp Neurol 422:123-139.

Whitaker WR, Faull RL, Waldvogel HJ, Plumpton CJ, Emson PC, and Clare JJ. 2001. Comparative distribution of voltage-gated sodium channel proteins in human brain. Brain Res Mol Brain Res 88:37-53.

Wolf S, Barton D, Kottschade L, Grothey A, and Loprinzi C. 2008. Chemotherapy-induced peripheral neuropathy: prevention and treatment strategies. Eur J Cancer 44:1507-1515.

Xiao W, Naso L, and Bennett GJ. 2008. Experimental studies of potential analgesics for the treatment of chemotherapy-evoked painful peripheral neuropathies. Pain Med 9:505-517.

Xie YF, Huo FQ, and Tang JS. 2009. Cerebral cortex modulation of pain. Acta Pharmacol Sin 30:31-41.

Yu FH, and Catterall WA. 2003. Overview of the voltage-gated sodium channel family. Genome Biol 4:207.

Zhang H, Li Y, de Carvalho-Barbosa M, Kavelaars A, Heijnen CJ, Albrecht PJ, and Dougherty PM. 2016. Dorsal Root Ganglion Infiltration by Macrophages Contributes to Paclitaxel ChemotherapyInduced Peripheral Neuropathy. J Pain.

Zhao P, Waxman SG, and Hains BC. 2006. Sodium channel expression in the ventral posterolateral nucleus of the thalamus after peripheral nerve injury. Mol Pain 2:27.

Zhuo M. 2008. Cortical excitation and chronic pain. Trends Neurosci 31:199-207. 


\section{Figure 1 (on next page)}

Effects of paclitaxel on sodium channel alpha subunits transcript levels in the anterior cingulate cortex (ACC)

Relative mRNA expression of sodium channel alpha subunits $\mathrm{Na}_{v} 1.1, \mathrm{Na}_{v} 1.2, \mathrm{Na}_{\mathrm{v}} 1.3$ and $\mathrm{Na}_{\mathrm{v}} 1.6$ in the $\mathrm{ACC}$ of $B A L B / C$ mice $(A)$ vehicle-treated mice versus untreated mice. Each bar represents the mean \pm S.E.M of the values obtained from 4 untreated mice and 4 vehicle-treated mice. (B) Relative mRNA expression of sodium channel alpha subunits on day 7 after first administration of the drug or its vehicle. Each bar represents the mean \pm S.E.M of the values obtained from 9-11 vehicle-treated mice and 12 paclitaxel-treated mice. ${ }^{* *} \mathrm{p}<$ 0.01 compared to vehicle-treated mice. 

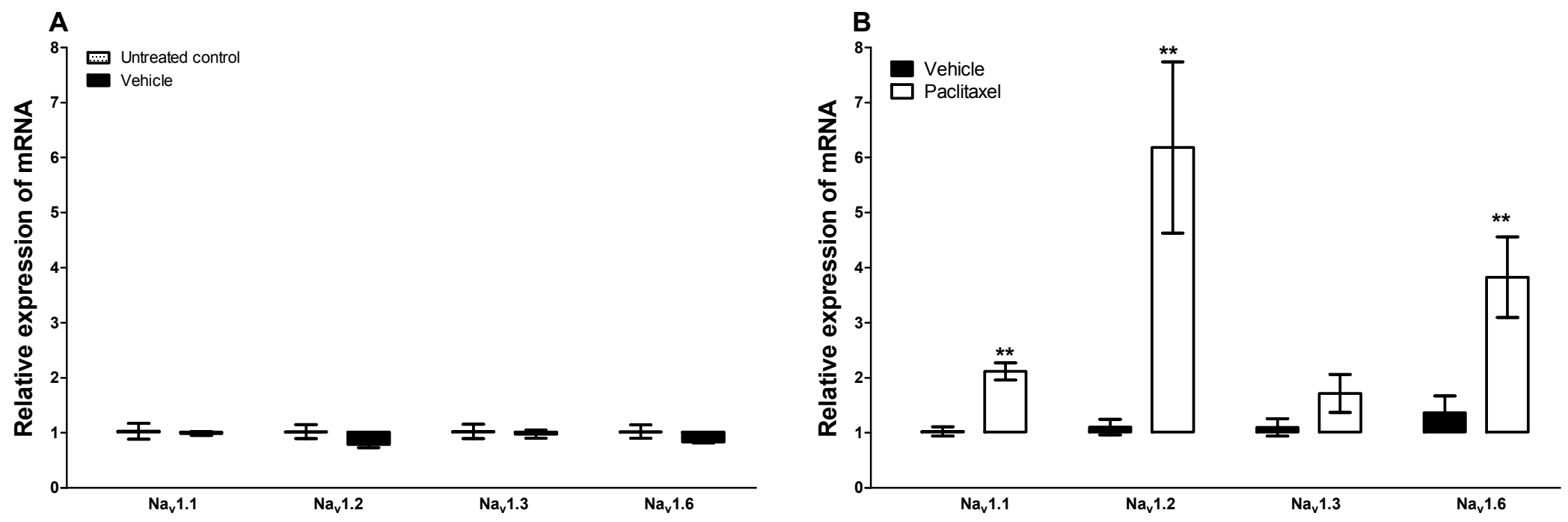


\section{Figure 2 (on next page)}

Effects of paclitaxel on the sodium channel alpha subunit $\mathrm{Na}_{\mathrm{x}}$ transcript levels in the anterior cingulate cortex (ACC)

Relative mRNA expression of $\mathrm{Na}_{x}$ in the ACC of BALB/C mice $(A)$ vehicle-treated mice versus untreated mice. Each bar represents the mean \pm S.E.M of the values obtained from 4 untreated mice and 4 vehicle-treated mice. (B) Relative mRNA expression of sodium channel alpha subunits on day 7 after first administration of the drug or its vehicle. Each bar represents the mean \pm S.E.M of the values obtained from 11 vehicletreated mice and 12 paclitaxel-treated mice . ** $p<0.01$ compared to vehicle-treated control mice. 

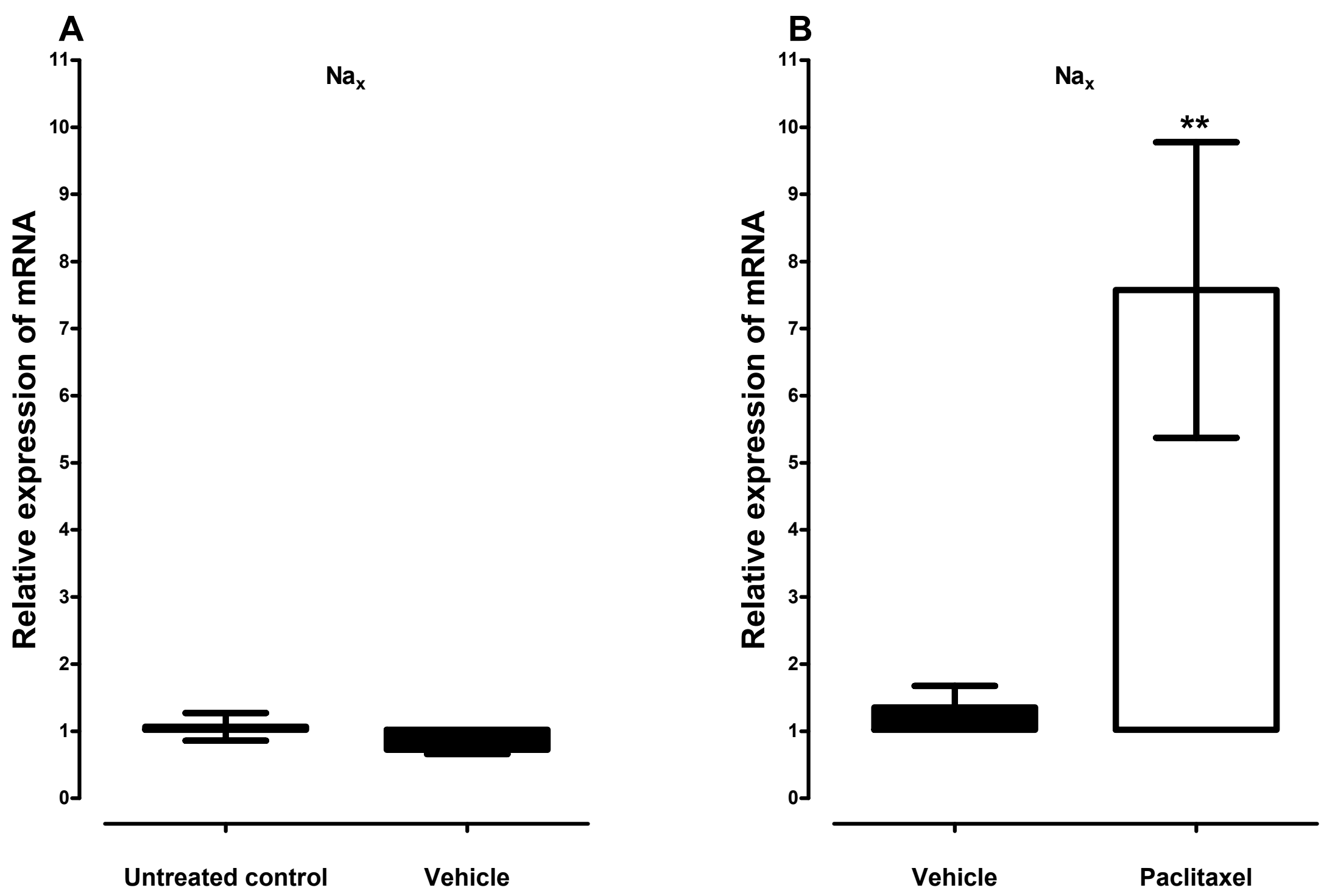


\section{Figure 3 (on next page)}

Effects of paclitaxel on sodium channel beta subunits transcript levels in the anterior cingulate cortex (ACC)

Relative mRNA expression of sodium channel beta subunits $N \mathrm{~N}_{v} \beta 1$ to 4 in the ACC of BALB/C mice $(A)$ vehicle-treated mice versus untreated mice. Each bar represents the mean \pm S.E.M of the values obtained from 4 untreated mice and 4 vehicle-treated mice. ${ }^{*} p<0.05$ compared to untreated mice. (B) Relative mRNA expression of sodium channel alpha subunits on day 7 after first administration of the drug or its vehicle. Each bar represents the mean \pm S.E.M of the values obtained from 8-11 vehicle-treated control mice and 8-12 paclitaxel-treated mice. $* p<0.05$ and $* * p<0.01$ compared to vehicle-treated mice. 

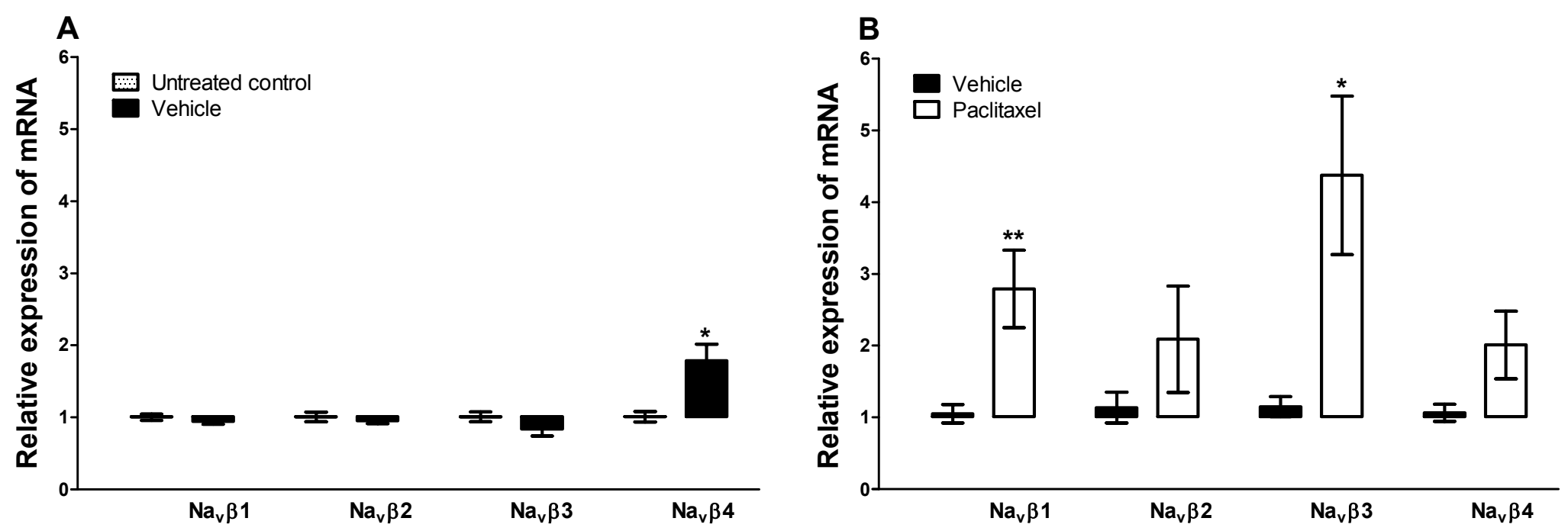


\section{Table $\mathbf{1}$ (on next page)}

PCR primer sequences of cyclophilin, and sodium channel subunits 
1 Table 1. PCR primer sequences of cyclophilin, and sodium channel subunits

\begin{tabular}{|c|c|c|}
\hline \multirow[t]{2}{*}{ Gene } & \multicolumn{2}{|l|}{ Polarity } \\
\hline & \begin{tabular}{|l|} 
Sense \\
Sequence 5'to 3'
\end{tabular} & \begin{tabular}{|l|} 
Anti-sense \\
Sequence 5'to 3'
\end{tabular} \\
\hline Cyclophilin & GCTTTTCGCCGCTTGCT & CTCGTCATCGGCCGTGAT \\
\hline $\mathrm{Na}_{\mathrm{v}} 1.1$ & AACAAGCTTCATTCACATACAATAAG & AGGAGGGCGGACAAGCTG \\
\hline $\mathrm{Na}_{\mathrm{v}} 1.2$ & GGGAACGCCCATCAAAGAAG & ACGCTATCGTAGGAAGGTGG \\
\hline $\mathrm{Na}_{\mathrm{v}} 1.3$ & GGGTGTTGGGTGAGAGTGGAG & AATGTAGTAGTGATGGGCTGATAAGAG \\
\hline $\mathrm{Na}_{\mathrm{v}} 1.4$ & CGCGCTGTTCAGCATGTT & CTCCACGTCCTTGGACCAAG \\
\hline $\mathrm{Na}_{\mathrm{v}} 1.5$ & AGACTTCCCTCCATCTCCAGATA & TGTCACCTCCAGAGCTAGGAAG \\
\hline $\mathrm{Na}_{\mathrm{v}} 1.6$ & AGCAAAGACAAACTGGACGATACC & CACTTGAACCTCTGGACACAACC \\
\hline $\mathrm{Na}_{\mathrm{v}} 1.7$ & TCCTTTATTCATAATCCCAGCCTCAC & GATCGGTTCCGTCTCTCTTTGC \\
\hline $\mathrm{Na}_{\mathrm{v}} 1.8$ & ACCGACAATCAGAGCGAGGAG & ACAGACTAGAAATGGACAGAATCACC \\
\hline Nav1.9 & TGAGGCAACACTACTTCACCAATG & AGCCAGAAACCAAGGTACTAATGATG \\
\hline $\mathrm{Na}_{\mathrm{x}}$ & TGTCTCСТCТАAACТСССТCAG & TGCGTAAATCCCAAGCAAAGT \\
\hline $\mathrm{Na}_{\mathrm{v}} \beta 1$ & GTGTATCTCCTGTAAGCGTCGTAG & ATTCTCATAGCGTAGGATCTTGACAA \\
\hline $\mathrm{Na}_{\mathrm{v}} \beta 2$ & GGCCACGGCAAGATTTACCT & CACCAAGATGACCACAGCCA \\
\hline $\mathrm{Na}_{\mathrm{v}} \beta 3$ & ACTGAAGAGGCGGGAGAAGAC & GGTGAGGAAGACCAGGAGGATG \\
\hline $\mathrm{Na}_{\mathrm{v}} \beta 4$ & CCCTTGGTGTAGAAACTAAGCAGAG & CAGAAGCGAGTCAGTCAGATACG \\
\hline
\end{tabular}

